\title{
急に始まる激逐動時の循桭反応に及ぼすウォーミンク・アップの効果
}

\author{
権 五 苌* 鍋 倉賢 治* 池上 晴 夫** \\ EFFECTS OF WARMING-UP ON CIRCULATORY \\ RESPONSES TO SUDDEN STRENUOUS EXERCISE
}

\author{
Osung Gwon, Yoshiharu Nabekura and Haruo Ikegami
}

\begin{abstract}
A study was conducted to elucidate the changes in circulatory responses to sudden strenuous exercise (SSE) using beat-by-beat analysis of heart rate (HR), stroke volume (SV) and blood pressure (BP). The effects of warming-up on these responses were also studied.

Six healthy male students volunteered for the study. A bicycle ergometer was prepared for SSE. The intensity and duration of SSE were $100 \% \quad \mathrm{~V}_{2} \max$ and $1 \mathrm{~min}$, respectively. Warming-up of $80 \% \mathrm{~V}_{2} \max$ for $5 \mathrm{~min}$ followed by SSE. The interval between SSE and warming-up varied from 5 to $30 \mathrm{~min}$. A control experiment was also performed without warming-up.

The main results obtained were as follows:

1) BP decreased in the initial stage of SSE, followed by a steep increase. This temporary drop in BP was prevented by warming-up. This might contribute to the prevention of myocardial ischemia which is occasionally observed in the initial stage of SSE without warming-up.

2) Time constants of $\mathrm{HR}$ and SV during SSE were shortened by warming-up with long intervals, while the time constant of BP was shortened when the interval was short.

3) The recovery response of each parameter was accelerated by warming-up, but the effect of warming-up had almost disappeared after a $30 \mathrm{~min}$ interval.

These results suggest the following conclusions:

Warming-up accelerates the up-stroke and recovery of circulatory responses to SSE, but these effects of warming-up are strongly influenced by interval time. In particular, the effect of recovery acceleration is almost abolished by a $30 \mathrm{~min}$ interval.
\end{abstract}

(Jpn. J. Phys. Fitness Sports Med. 1991, $40: 174 \sim 186$ )

key words : 1) Sudden strenuous exercise, 2) Warming-up, 3) Heart rate, 4) Stroke volume, 5) Blood pressure

\section{I. 锖}

スポーツ場面では安静状態から急に激しい運動 (sudden strenuous exercise, 以下 SSE)へ移行す る場合が少なくない.しかし SSE 中及びその回 復時の循環反応の詳細に関しては研究報告が少な くまだ明らかでないことが多いここのような場 合の循環反応は变化が急激であるためその詳細を
明らかにするためには, beat-by-beat の測定デ 一タに基づく検討が望ましいが，心拍数に関する 研究を除けばまだそのような報告はあまりなく， 特に血圧や一回拍出量の経時変化に関しては, 研 究がほとんどなされていない。

事前にウォーミング・フップ(以下 W-up)を行 らと，それに引き続いて行われる SSE 時の生理 機能の運動適応を加速し，パフォーマンスを高め

\footnotetext{
*筑波大学体育科学研究科

University of Tsukuba, Doctoral Program in Health and Sports

干305 茨城県つくば市天王台1-1-1 Science, Tsukuba-city, Ibaraki 305

**筑波大学体育科学系

University of Tsukuba, Institute of Health and Sports Science,

干305 茨城県つくば市天王台1-1-1 Tsukuba-city, Ibaraki 505
} 


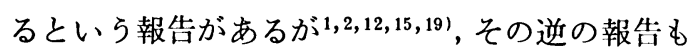
ある ${ }^{23,26)}$. 拈そらくW-up と主運動の強度や持続 時間あるいはインターバル・タイム（以下インタ ーバル）の違い等によって，W-up の効果が異な るためであろらと考えられる.

また SSE 初期には左室心筋収縮力を示寸左心 室圧の時間微分值 $(\mathrm{LVdp} / \mathrm{dt})$ の減少や，心電図に ST 低下などの心筋虚血像が起こることが知られ ている ${ }^{4,5,7,9,10,16,24)}$. このような SSE 時に見られ る循環系の異常な反応も W-up によって防止で きることが報告されている4,5,10,16). しかし SSE 時に循環系が上記のような異常反応を起こすメカ ニズム及びそれに対する W-up による予防効果 のメカニズムに関してはまだ明らかでない点が少 なくない。この点に関しては多くの循環パラメー ターを同時に测定して，多元的に検討する必要が ある。

そこで本研究では, SSEによって起こる循環動 態の変化を心拍数, 一回拍出量及び血圧の beatby-beat のデータを指標として明らかにすると同 時に, SSE 時の循環反応に対するW-up の効果と, その効果消失の経時変化を明らかにすることを目 的とした。

\section{II. 方法}

\section{A. 被験者}

健康な男子学生 6 名を用いた。 その身体特性を Table 1 に示す.

\section{B. 実験手順}

運動は自転車エルゴメーターを用いて行い,ペ

Table 1. Physical characteristics of the subjects.

\begin{tabular}{llr}
\hline Number of subjects & \multicolumn{1}{c}{6} \\
Age & $($ year $)$ & $25.8 \pm 3.2$ \\
Height & $(\mathrm{cm})$ & $171.1 \pm 1.7$ \\
Weight & $(\mathrm{kg})$ & $65.7 \pm 5.4$ \\
Rest HR & $(\mathrm{bpm})$ & $80.6 \pm 6.6$ \\
Rest SBP & $(\mathrm{mmHg})$ & $128.1 \pm 10.8$ \\
Rest DBP & $(\mathrm{mmHg})$ & $67.3 \pm 7.0$ \\
$\dot{\mathrm{V}}{ }_{2} \max$ & $(l / \mathrm{min})$ & $3.3 \pm 0.7$ \\
$\dot{\mathrm{VO}}{ }_{2} \max$ & $(\mathrm{ml} / \mathrm{kg} / \mathrm{min})$ & $50.5 \pm 11.0$ \\
\hline
\end{tabular}

ダルの回転数は $60 \mathrm{rpm}$ とした. 予め漸增負荷法 によって測定した $\dot{\mathrm{V}} \mathrm{O}_{2} \max$ を基準にして，100\% $\dot{\mathrm{V}} \mathrm{O}_{2} \max$ 強度での 1 分間の運動を SSE とし, Wup としては $80 \% \dot{\mathrm{VO}}_{2} \max$ 強度の 5 分間運動を用 いた. W-up と SSE 間のインターバルは 5 分, 10分及び30分の 3 条件 (以下それ ぞれ W-up(5), $\mathrm{W}-\mathrm{up}(10)$ 及び W-up(30)] とし, コントロールと してW-up を行わない実験を加兊た。

\section{C. 測定及び分析}

測定項目は心電図 (CM 5 誘導法), インピーダ ンス・カルジオグラム(三栄測器社製7746), 耳架 脈微分波及び血圧 (Omeda Finapress beat-bybeat 自動血圧計) であった．耳染脈微分波は光電 式ピックアップ(日本光電社製)によって耳架から 導いた脈波を, 微分アンプ (日本光電社製, ED600 型)によって時定数 $10 \mathrm{msec}$ で微分して求め た.これらの現象を SSE 開始 4 分前から終了後 10 分目まで連続してデータ・レコーダー (TEAC 社製 XR-510)に収録した. 後刻それを再生し、コ ンピューター(Sord 社製 M 68-MX) を用い池上 たち ${ }^{14)}$ ，及び鍋倉たち ${ }^{20)}$ の方法によって心拍数，

一回拍出量, 収縮期血圧, 拡張期血圧, 心拍出量, 及び心拍出量と平均血圧から算出した末梢血管抵 抗を beat-by-beat モードで自動計測した.

また各条件間の比較を容易にするため SSE 前 4 分間と回復 3 分目から10分目までは 1 分毎に, $\mathrm{SSE}$ 中は 5 秒毎に, SSE 終了直後から回復 2 分ま では10秒毎に，それぞれ 6 名の平均值を求めた. また, SSE 直前值から SSE 中のピーク值までの 変化量及び SSE 中のピーク值から回復時の変化 量を 1 分毎に求めた。 また SSE 開始時の反応の 速さ及び終了後の回復の速さを比較するために， Symplex 法 ${ }^{171}$ によって時定数 $(\tau)$ を求めた. 回復 時の時定数の算出に沶いては, 先行研究のレビュ -17により，各パラメーターの時定数の約 3 倍に なる時間(心拍数と心拍出量においては回復 3 分, 一回拍出量と収縮期血圧においては回復 5 分）ま での全データを用いた。

\section{D. 統計処理}

各平均値間の有意差検定には Paird-t-test を 用い, 有意水準の判定は全て $5 \%$ とした. 
(a)

\section{HR}

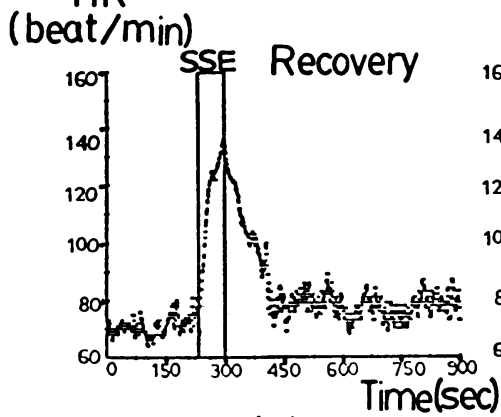

(c) (b)

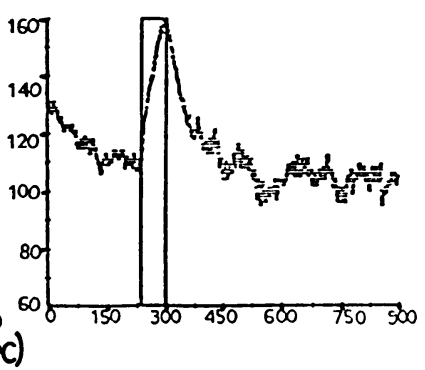

(d)
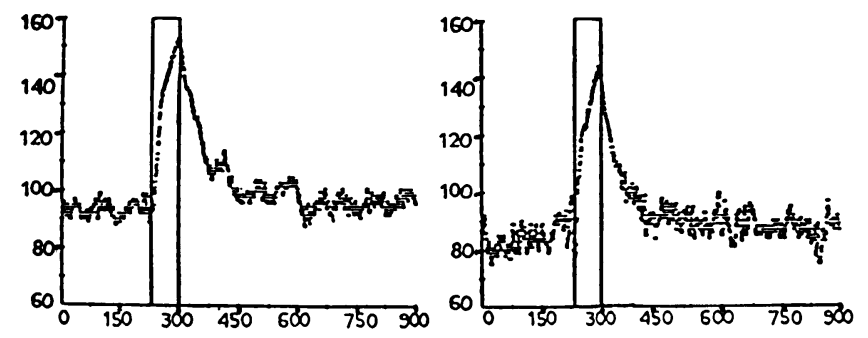

Fig. 1. Changes of heart rate shown by beat-by-beat mode in three experimental conditions and control. (subject I. S.) (a) : control, (b) : W-up(5), (c) : W-up(10), (d) : W-up $(30)$.

\section{III. 結 果}

\section{A. 心拍数}

beat-by-beat モードによる測定結果の 1 例を 図1に示した。，心拍数は SSE 開始とともに急激 に増加し始め, SSE 終了時点ではピークを示した. SSE 終了後は最初の $1 \sim 2$ 分の急激に減少する フェースと, それ以後の徐々に回復するフェース の二つに分けられる.コントロール実験（以下ュ ントロール) においては SSE 15〜24 秒目にノッ チが生じた.このノッチはW-up を行らと消失す る傾向を示し，特にインターバルが短い時には完 全に消失し，インターバルが長くなると再び出現 した.この現象は 6 人の全被験者で明らかに認め られ，その出現時間及び出現時の心拍数には個人 差が少なく，平均值はそれぞれ SSE 開始後18.0土 3.9 秒及び $124.3 \pm 6.9 \mathrm{bpm}$ であった.

6 人の平均値を図 2 に示した. SSE 前値, SSE ピーク値及び回復時の值はいずれも W-up した 方がュントロールより高く, その傾向はインター

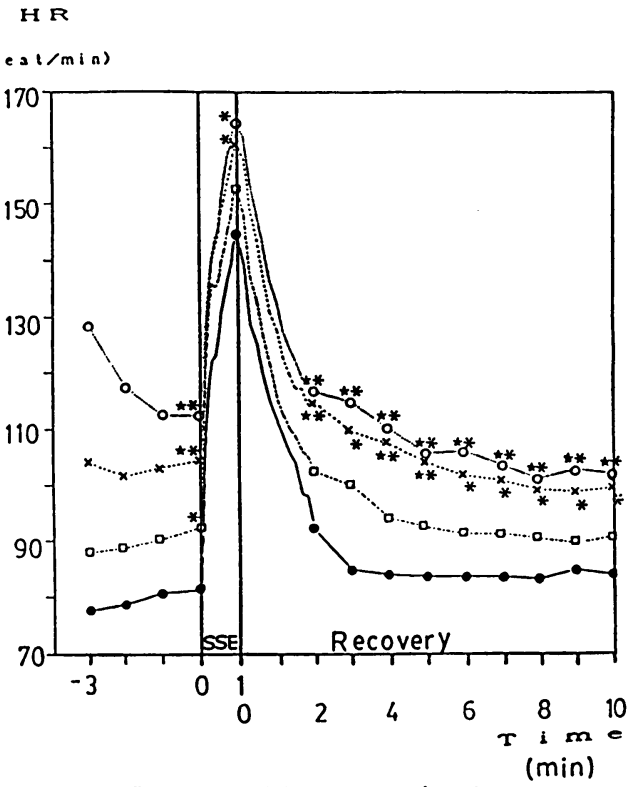

Fig. 2. Changes of heart rate in three experimental conditions and control. : control, $\mathrm{O}: \mathrm{W}-\mathrm{up}(5), \times: \mathrm{W}-\mathrm{up}(10), \square: \mathrm{W}-\mathrm{up}(30)$, $*$ : significant difference from control $(\mathrm{p}<$ $0.05), \star$ : significat difference from $\mathrm{W}-\mathrm{up}$ $(30)(\mathrm{p}<0.05)$. 

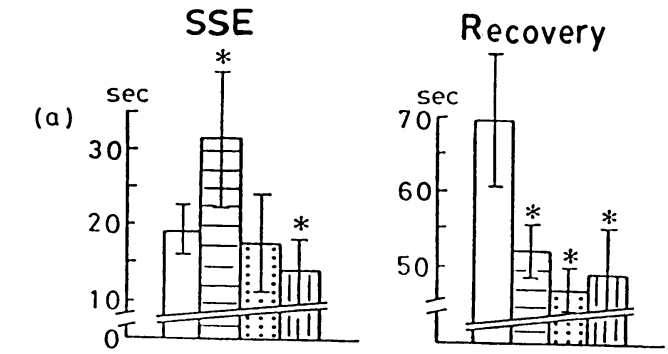

(b)

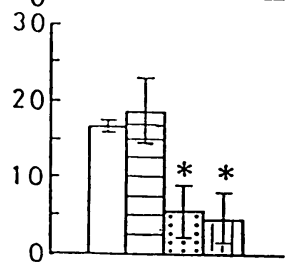

(c)

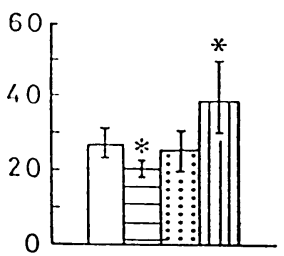

(d)
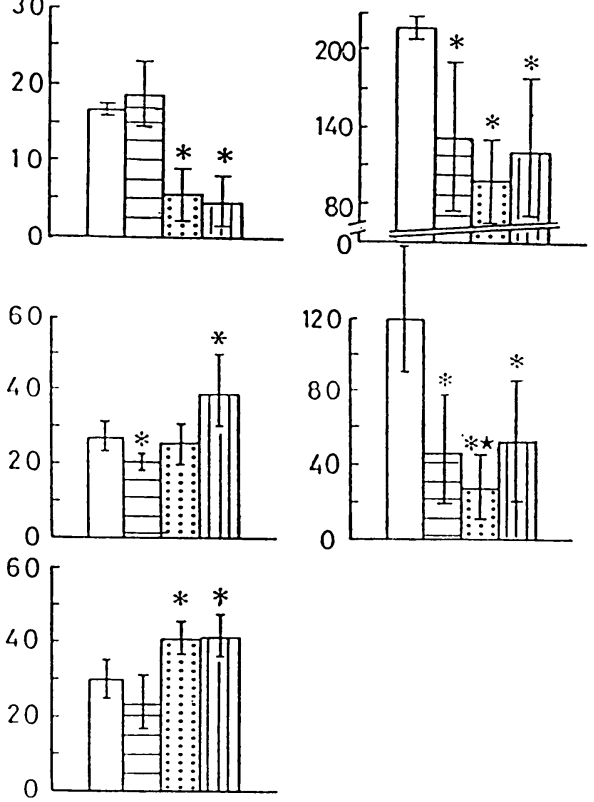

Fig. 3. Time constant $(\tau)$ of heart rate (a), stroke volume(b), systolic(c), and diastolic blood pressure (d) during SSE and recovery period in three experimental conditions and control. * : significant difference from control $(\mathrm{p}<0.05), \star$ : significant difference from $\mathrm{W}$ up $(30)(\mathrm{p}<0.05)$.

$\square:$ Control,, :U-up(s),

バルが短いほど顕著であった。

時定数をみると(図 $3, a)$ ， まず SSE 時にはコ ントロールに比して W-up(5)では有意に延長し， 立ち上がりが遅くなった。しかし W-up $(10)$ では コントロール值に回復し,さらに W-up(30)では かえって短くなりコントロール值との間に有意 な差が生じた. 回復時の時定数は SSE 時のそれ より著しく長かったが，W-upによって有意に短 縮した.

$\mathrm{SSE}$ 時の変化量をみると(図 $4, \mathrm{a})$, コントロー

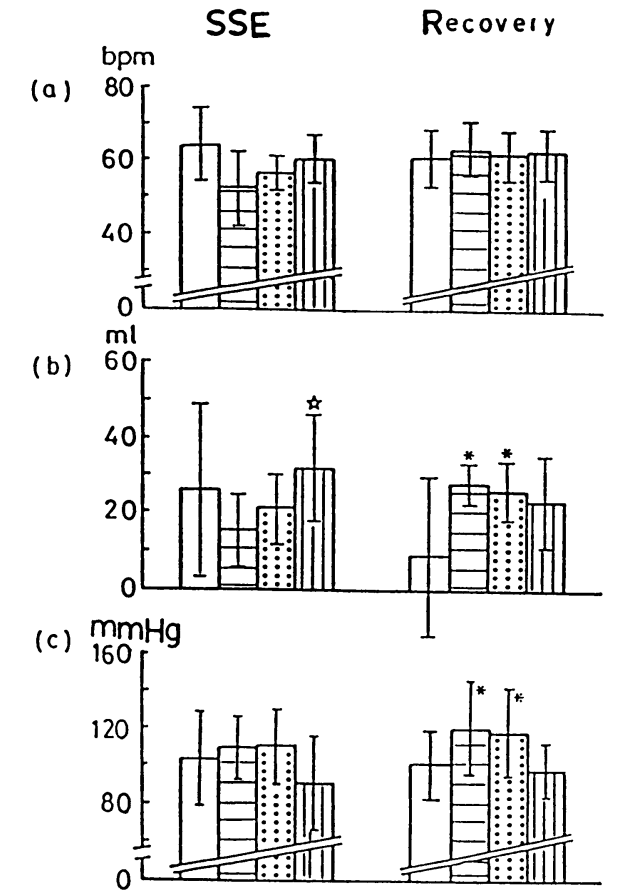

(d)

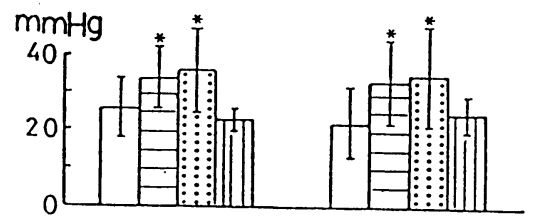

Fig. 4. Changes of $\Delta \mathrm{HR}(\mathrm{a}), \Delta \mathrm{SV}(\mathrm{b}), \Delta \mathrm{SBP}$ (c) and $\triangle \mathrm{DBP}(\mathrm{d})$ during SSE and recovery period (point of ten minutes) in three experimental conditions and control. * : significant difference from control $(\mathrm{p}<0.05)$, is : significant difference from $\mathrm{W}-\mathrm{up}(5)(\mathrm{p}<0.05)$.

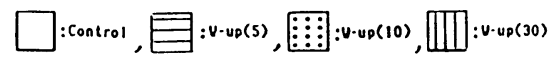

ルに比して W-up を行った場合には減少傾向を 示したが, インターバルを長くすると再びュント ロール值に近づく傾向を示した。

\section{B. 一回拍出量}

beat-by-beat モードによる測定結果の 1 例を 図 5 に示した. SSE 中から SSE 後にかけて増加 寸る傾向がうかがえるが，変動が激しい. SSE 開 始前には, コントロールでは約 $30 \mathrm{ml}$ の範囲で変 動しているのに対して W-up の場合には変動幅 が大きかった (約 $60 \mathrm{~m} l$ ). SSE 開始とともに変動 幅はさらに増大した. コントロールでは SSE 終 


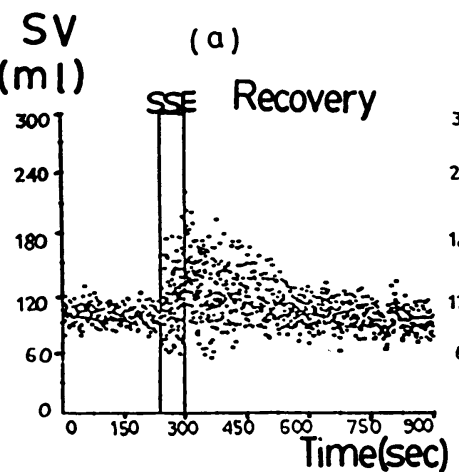

(c)

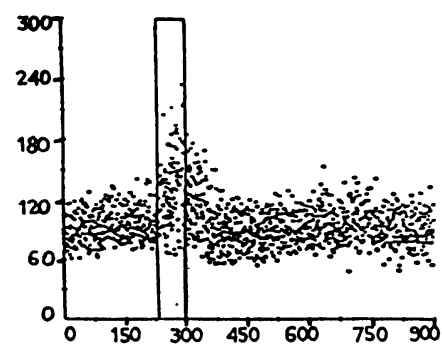

Fig. 5. Changes of stroke volume shown by beat-by-beat mode in three experimental conditions and control. (subject F. N.) (a) : control, (b) : W-up(5), (c) : W-up(10),(d) : W-up $(30)$.

了後も変動幅が大きく，4〜5 分かけてゆっくり 回復したのに対して，W-up した場合にはSSE 終 了とともに直ちに減少し, 変動幅も急减した。そ の傾向はインターバルが短いほど顕著であった.

6 人の平均值を図 6 に示した. SSE 前の安静値 はW-up した方がュントロールより高く，その程 度はインターバルが短いほど顕著であったが，い ずれも有意差ではなかった.一回拍出量はいずれ の条件においてもSSE開始とともに急増し, 15〜 20 秒目にほぼ一定値(約 $125 \mathrm{ml}$ ) に達し, その後は 多少変動したがほぼその一定值を保った. SSE 1 分間の平均値はコントロールで $118.1 \pm 20.3 \mathrm{ml}$ で あったのに対して W-up(5)では $124.6 \pm 21.7 \mathrm{ml}$, $\mathrm{W}-\mathrm{up}(10)$ では $126.1 \pm 28.0 \mathrm{ml}$ そして W-up(30) では $125.5 \pm 27.0 \mathrm{ml}$ を示し，W-up した方が大き かったがいずれる有意差ではなかった. SSE 終了 直後はいずれの条件においても一旦急増し，その 後 1 分間位は急减した後,リバゥンドしてから緩 やかに回復した.リバウンドはコントロールにお

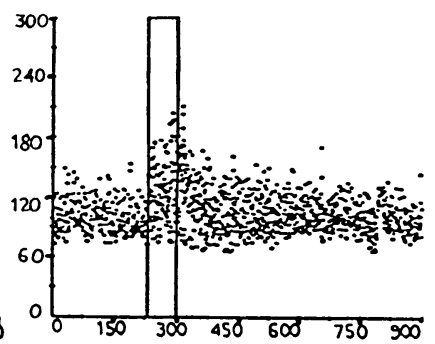

(b)

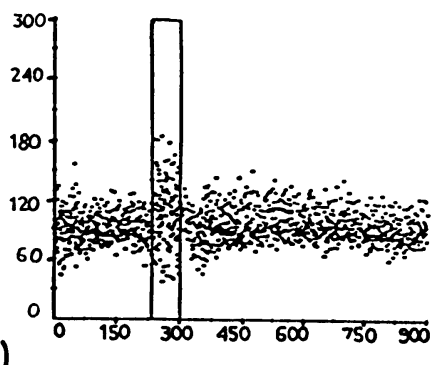

(d)

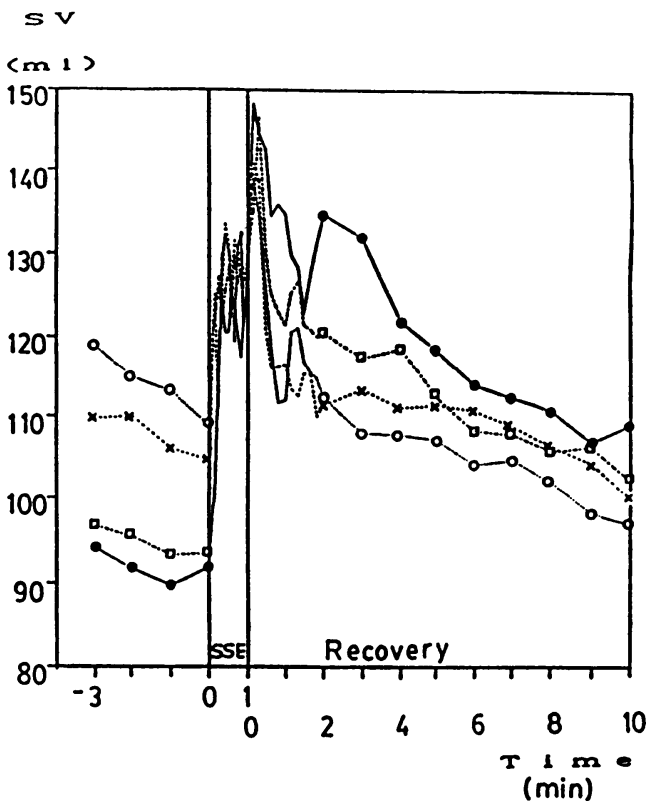

Fig. 6. Changes of stroke volume in three experimental conditions and control. : control, $\bigcirc: W-u p(5), \times: W-u p(10), \square: W-$ up (30). 
いて特に顕著であったが，W-up を行らとその程 度が減少する傾向を示し, 回復も全体としてWup によって加速された. 回復時の一回拍出量は コントロール, W-up(30), W-up(10), W-up(5) の順に大きい傾向を示し，これは心拍数がその逆 順であるのと対照であった。

時定数をみると(図 $3, b), \mathrm{SSE}$ 時にはコントロ 一ルに対して W-up(10)とW-up(30)の場合に有 意に短縮した．回復時には SSE 時より著しく長 かったが，W-up によって有意に短縮した。

変化量をみると(図 $4, \mathrm{~b}), \mathrm{SSE}$ 時にはコントロ ールに比して W-up を行った場合には减少傾向 を示したが，インターバルを長くすると再びュン トロール值に近づき，W-up(30) では逆にコント ロールよりも大きい傾向を示した. 回復時には (SSE 中の平均値一回復10分目の值)W-up した方 がいずれも大きくなった.

\section{C. 収缩期血圧}

beat-by-beat モードによる測定結果の 1 例を
図 7 に示した. SSE 開始とともに急激に増加しは じめ, SSE 終了時点ではピークを示した. 回復期 には，一旦急减しリバウンドしてから $2 \sim 3$ 分の 周期で上下に変動しながら回復する様子が認めら れた。この現象はコントロールと W-up(30)で顕 著であったが, W-up(5) と W-up(10)ではそれほ ぞ顕著ではなく比較的滑らかで素早い回復を示し た.

6 人の平均值を図 8 に示した。いずれの場合に も SSE 開始とともに急増し始めたが，コントロ 一ルに打いて $5 \sim 10$ 秒の間に有意な一時的低下が 見られた．この現象は W-up によって消失する 傾向を示したが, W-up(30) では再び出現した. SSE 中のピーク值はコントロールに比して，Wup(5) と W-up(10)では高く, W-up(30)では逆に 低い傾向を示した．回復時の值はコントロールで 最も大きく，W-up した場合にはそれより一般に 小さい值を示した.

SSE 時の時定数 (図 $3, \mathrm{c}$ ) はコントロールに比 (a)

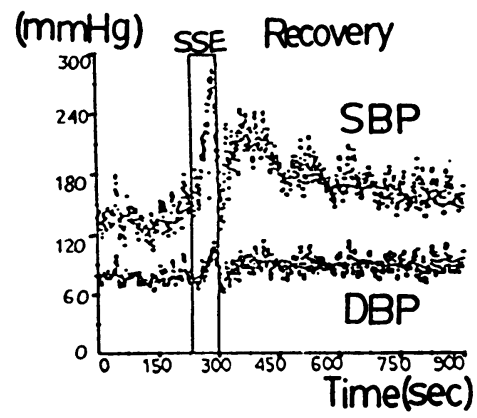

(c)

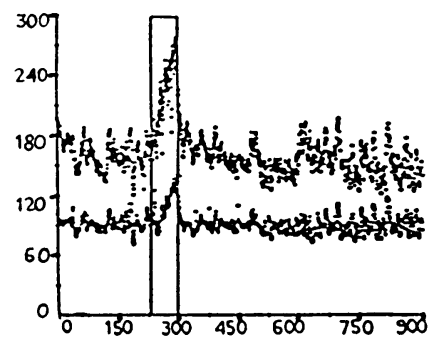

(b)

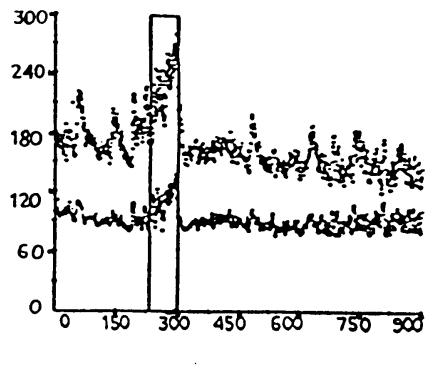

(d)

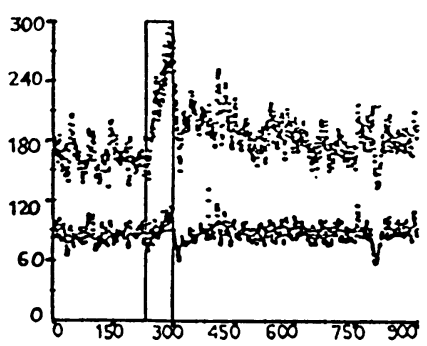

Fig. 7. Changes of systolic and diastolic blood pressure shown by beat-by-beat mode in three experimental conditions and control. (subject F. N.) (a) : control. (b) : W-up(5), (c) : W-up(10), (d) : W-up(30). 


$$
S B P
$$

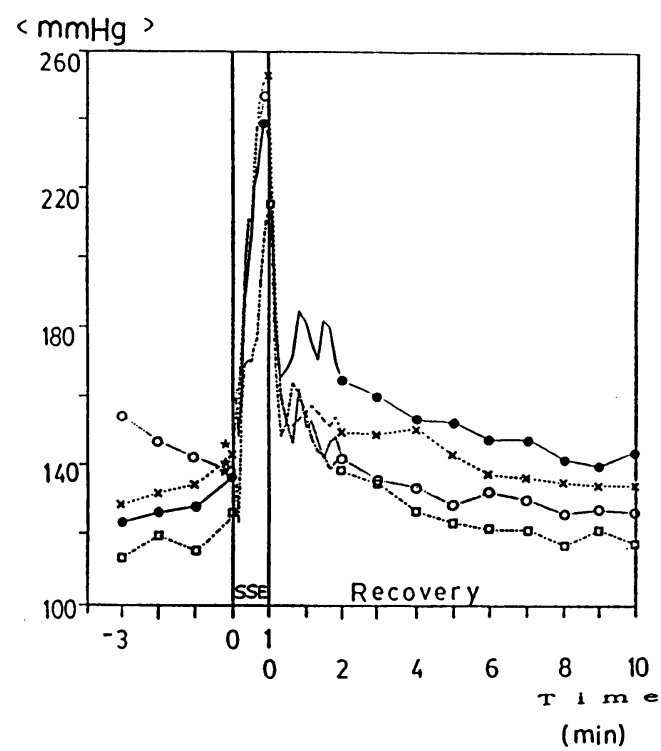

Fig. 8. Changes of systolic blood pressure in three experimental conditions and control. : control, $\bigcirc: W$-up (5), $\times: W$-up (10), $\square: W-u p(30), \star$ : significant difference from $\mathrm{W}-\mathrm{up}(30)(\mathrm{p}<0.05)$.

して，W-up(5)では有意に短縮し，立ち上がりが 速くなったことを示した。 しかし W-up(10)では コントロール值に回復し，さらに W-up(30)では 逆に有意に長くなった. 回復時の時定数は SSE 時 のそれより著しく長かったが, W-upによって顕 著に短縮した。

回復時の変化量 (図 $4, \mathrm{c}$ ) は W-up $(5)$ と W-up (10)に扣いてはコントロールより有意に大きかっ たが，W-up(30)に执いてはコントロール値に戾 った.

\section{D. 抎張期血圧}

beat-by-beat モードによる測定結果の 1 例を 図 7 に示した.SSE 開始とともに収縮期血圧とほ ぼ同じような変化パターンで上昇しはじめ, SSE 終了時点ではピークを示した。しかし変動の幅は 収縮期血圧の場合より小さかった. SSE 終了直後 いずれの条件においても一旦 SSE 前值以下まで 急減した後, SSE 前値まで戻る傾向が見られた.

6 人の平均値を図 9 に示した. コントロール, W-up(5)及び W-up(10)は SSE 開始とともに増

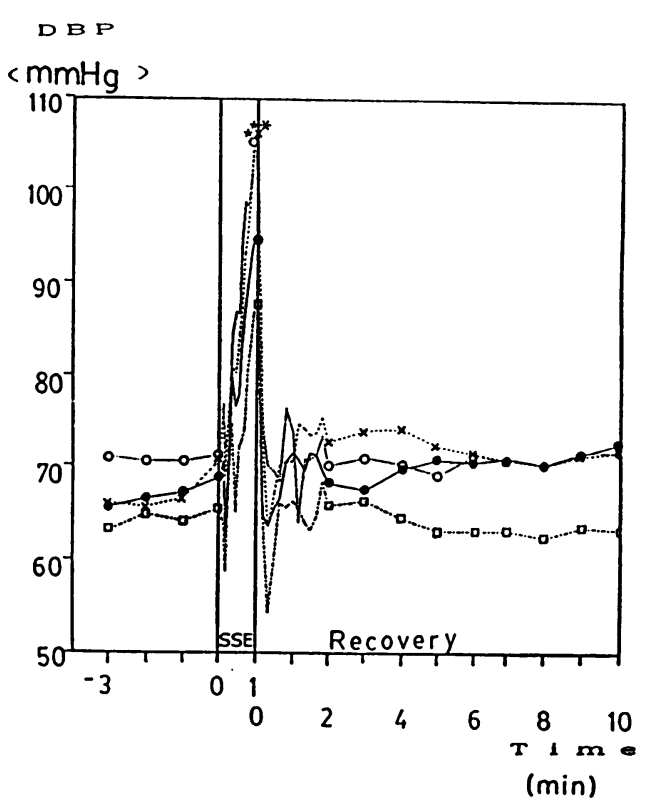

Fig. 9. Changes of diastolic blood pressure in three experimental conditions and control. : control, $\bigcirc: W-$ up (5), $\times: W$-up (10), $\square$ : W-up $(30), *$ : significant difference from control $(p<0.05), \star$ : significant difference from $W-u p(30)(p<0.05)$.

加したが， 5 〜10秒の間に一時的に減少し，その 後再び増加し始め, SSE 終了時点でピークを示し た. W-up(30)に执いてはSSE開始とともに10秒 目まで減少した後增加し始め, SSE 終了時点では ピークを示した. SSE ピーク值はコントロールに 対して W-up(5)と W-up(10)の場合は高く, 特 に W-up(10)の值は有意に高かった。 しかし Wup(30) そ沶いてはコントロール值よりも低くな る傾向を示した. SSE 終了後はいずれの条件にお いても素早い回復を示し, 10 秒以内に SSE 前值 あるいはそれ以下の値まで急堿した後 SSE 前值 に戻った。

SSE 時の時定数 (図 3,d) はコントロールに対 して W-up(5)は短縮する傾问を示したが，W-up (10) と W-up(30)は逆に延長した. 回復時の時定 数は, 払張期血圧の変化パターンが図 8 に示した ように単純でないため, 算出できなかった.

変化量をみると(図 4, d), SSE 時にはコント ロールに対して W-up(5)と W-up(10)は有意に 


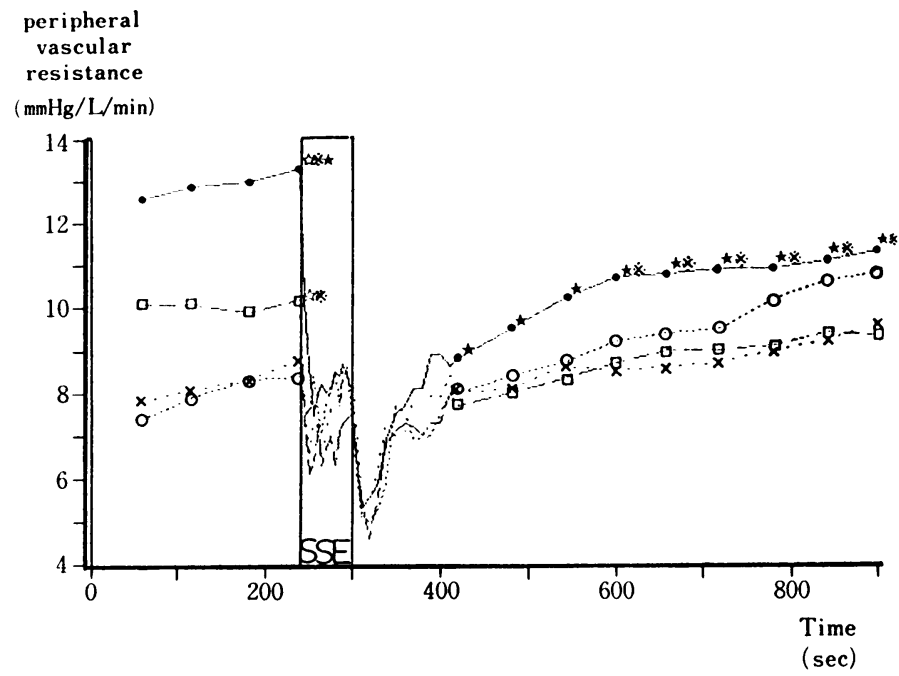

Fig. 10. Changes of peripheral vascular resistance in three experimental conditions and control. : control, $\bigcirc: \mathrm{W}-\mathrm{up}(5), \times: \mathrm{W}-\mathrm{up}(10), \square: \mathrm{W}-\mathrm{up}(30)$, s $:$ significant difference from $\mathrm{W}-\mathrm{up}(5)(\mathrm{p}<0.05), ※:$ significant difference from $\mathrm{W}-\mathrm{up}(10)(\mathrm{p}<0.05), \star$ : significant difference from $\mathrm{W}-$ up $(30)(\mathrm{p}<0.05)$.

大きかったが, W-up(30) はコントロール值に厌 った. 回復時にも W-up(5)と W-up(10)はコン トロールより大きかった.

\section{E. 末梢血管抵抗}

6 人の平均值を図10に示した. SSE 開始ととも に急減し， 5 秒目に最低值に達し，以後緩やかに 增加する傾向を示したＷ-up を行った場合には 最初から比較的に低值であったため, SSE による 変化は比較的軽かった. インターバルが長くなる につれてコントロールの変動パターンに戻る傾向 を示した. SSE 直前值から判断すると，末梢血管 抵抗は W-upによって顕著に低下する. そしてそ の効果は W-up 後 30 分経過した時点でもまだ半 分以上残っている.

IV. 考

察

\section{A. 心拍数}

心拍数は SSE 開始直後に急激な増加を示した 後, 一時的にレベリング・オフ状態となり，その 後再び上昇した. この現象は従来の研究において も観察されていて, “ノッチ”と呼ばれている 18). このノッチの発生機序として, 運動を開始す ると副交感神経緊張が低下することによって心拍
数が増加するが，その途中で副交感神経緊張が一 時的に增強するため心拍数の上昇が抑制されるの であると言われている ${ }^{17,18)}$. 本研究に打いて， W-up を行った場合にはこのノッチ現象が消失す る傾向を示し, 特に W-up(5)〜W-up(10)に打い てはほぼ完全に消失し，W-up(30) では再び出現 する兆候を示した。拈そらく W-up によって運 動開始時に副交感神経緊張が最初からある程度低 下していたことによるものと考えられる. SSE 直 前の心拍水準が W-up した場合の方がコントロ ールより高く，その程度はインターバルが短いほ ど顕著であったことはその裏付けになるだろう。

W-up が心拍数の立ち上がりの速さに及ぼす影 響はこれまで数多く報告されているが，その結果 は一致していない，W-upによって主運動時の心 拍数の立ち上がりが加速されたとする研究におい ては ${ }^{1,2,12,15)}$ ，主運動と W-up の間にある程度の インターバルが挿入れていたのに対して， W-upによって立ち上がりが遅くなったとする研 究に拈いては22,26)，インターバルを挾まなかった ものが多い. 本研究の結果では, 立ち上がりの速 さの指標である時定数は, インターバルが最も短 かった W-up(5) ではコントロールより長かった 
のに対して，インターバルが最も長かった W-up (30)ではコントロールより短かった. したがって, SSE 時の心拍数の立ち上がりの加速に及ぼすWup の効果はインターバルの有無やその長さによ って違っていて，インターバルが無いか，あるい は短い場合には時定数が長くなり,インターバル がある程度長い場合には時定数が短くなるものと 考えられる. 時定数が短くなる原因としては， W-upによって自律神経系を含む循環系の反応性 が高まった可能性が挙げられる、インターバルが 短いW-up では効果が見られなかったのは, SSE 前值が高かったことに原因があると見られる。し かしこれに関しては今後さらに検討する必要があ る.

回復時の時定数は W-upによって短縮し，回復 が加速したことを示した．その原因として，一つ は SSE 終了時点の心拍数が，W-up した場合の 方が高かったことが関係していると考えられる. しかしその他の原因として，乳酸消失等回復過程 が W-up によって加速されたことも関係してい るかもしれない. Hagberg et al. ${ }^{13)}$ は, トレーニ ングにより，同じ強度の運動を行った後の心拍数 の回復が加速されたと報告し，その原因として運 動中蓄積される乳酸量及び ATP, PC 系の利用量 が减少することによる $\mathrm{O}_{2}$ dept 及び $\mathrm{O}_{2}$ deficit の 減少を挙げている，一方後藤 ${ }^{11}$ は，血中乳酸を増 加させるような強いW-up を行らと，続いて行わ れる主運動時のピーク乳酸値及び主運動期間中蓄 積された乳酸量が有意に減少したと報告してい る.したがって本研究において W-up によって 心拍数の回復が加速された原因にも，SSE 時の乳 酸量の減少による $\mathrm{O}_{2}$ dept 及び $\mathrm{O}_{2}$ deficit の減少 が関係している可能性がある.

\section{B. 一回拍出量}

一般に，一回拍出量は運動強度が中等度以下の 場合にはそれに比例して増加するが，それ以上の 強度ではプラトーに達し，強度をより強くしても それ以上は増加しなくなると言われている3゙. 本 研究の SSE においては，一回拍出量は他の循環 パラメーターに比べて上昇の時定数が短く, 速く プラトーに達した.
Duncan et al. ${ }^{8)}$ はイ スを使った実験において， $\mathrm{SSE}$ 初期に LVdp/dt と一回拍出量が一時的に低 下したと報告している。また Duncan et al.7”は SSE 初期の LVdp/dt の減少をW-up によって 防止できたと報告しており，Forster et al. ${ }^{10)}$ も SSE 時に見られた心筋収縮力の指標である左室 駆出率〔(拡張末期容量一収縮末期容量)/払張末 期容量, 以下 [VEF] の減少を, W-up によって 抑制することができると報告している．したがっ てW-upによって SSE 時の一回拍出量の低下が 防止でき，また立ち立がりの速さが加速される可 能性が考えられる. 本研究に打ける一回拍出量の beat-by-beat モードの測定結果では, beat 毎の 変動が大きくて，一時的低下があったかどうかは 判断できなかった。 また 6 人平均値の絶対值と変 化量での比較においても，コントロールと W-up の間に有意差は認められなかった。しかし時定数 は, W-up(10)と W-up(30)において, コントロ ールより有意に短縮した．時定数が短縮する原因 としては，W-upによって静脈還流が促進された り，自律神経系を含む循環系の反応性が高まった 結果, SSE 初期の LVdp/dt の低下及び SSE 中 の LVEF の低下が改善されたことが考えられる. W-up(5) で効果が見られなかったのは, SSE 前 値がかなり高かったことが関係していると考えら れる.

SSE 終了直後, いずれの条件においても一回拍 出量の急增現象が認められた. その原因としては 末梢血管抵抗の减少, すなわち後負荷の減少が挙 げられる、また心拍数の急减によって払張期が急 増し，前負荷を増大させることも一因になってい る可能性がある. 一方 Forster et al.91 は SSE の 突然停止が LVEF の著しい增加をもたらしたと 報告している. したがって LVEF の増加も関係 しているのかもしれない. LVEF が増加した原因 は前負荷の増大によって説明できようが，払張期 の増加により冠血流が改善されて，心筋収縮力の 昂進をもたらした可能性も否定できない，これに 関しては今後さらに検討する必要がある.

回復時の時定数は W-up によって著しく短縮 した. また変化量も W-up した方がコントロー 
ルに比して大きかった.これは W-up によって 一回拍出量の回復が加速されたことを意味してい る. その原因としては，心拍数の場合と同しょら に, SSE 時の血中乳酸量の減少による $\mathrm{O}_{2}$ dept 及 び $\mathrm{O}_{2}$ deficit の減少が考えられる. しかしW-up (30)ではコントロールとの間に有意差が認められ なかった，後藤 ${ }^{11}$ は W-up の血中乳酸蓄積を抑 制する効果は, インターバルが短いほど顕著であ りインターバルが長くなると効果がなくなると 報告している. したがって本研究においてみられ た W-up の回復時の変化量を大きくする効果も， インターバルが長くなると消失するのであろらと 考えられる. しかし今回の結果と乳酸との関係に ついては，実際に乳酸を測定して検討することが 必要である.

回復時の一回拍出量はコントロール, W-up (30), W-up(10), W-up(5) の順に大きく，これ は心拍数がその逆順であるのと対照であった。 心 拍数の場合, SSE 前, SSE 時及び回復時ともにコ ントロールょり W-up した場合の方が大きく，そ の傾向はインターバルが短いほど顕著であった が, SSE 時と回復時の変化量は条件別に差がなか ったことから, SSE 時と回復時においての条件別 の差は SSE 前值の差によるものと考えられる. 一方一回拍出量に沶いては, SSE 前は心拍数と同 じ傾向であったものの, 回復時の変化量が W-up によって有意に大きくなり，またその効果はイン ターバルが短いほど顕著であった結果, 心拍数と は逆の様相を呈したものと考えられる.

\section{C. 血圧及び末梢血管抵抗}

SSE 時に収縮期血圧は急增し，払張期血圧もよ り軽度ではあるが上昇した。一般にダイナミック な運動時には払張期血圧はあまり上昇しないとさ れているが，今回上昇した原因としては強い自転 車エルゴメーター運動が isometric 的運動要素を 含んでいることが挙げられる ${ }^{21)}$. Buckberg et al. ${ }^{61}$ は, 心筋への酸素供給は拡張期の冠血流量に 大きく依存して拈り，拡張期血圧の低下は冠血流 量の減少をむたらすと報告している.つまり払張 期血圧の上昇は心筋への酸素供給の点ではむしろ 望ましいので, SSE 時のような心筋酸素不足にな
りやすい運動の場合には, 拡張期血圧の上昇は 必ずしも不利な条件ではないと考光られる. Barnard et al.") は SSE 時に拡張期血圧が低下し たと報告しているが，その研究に拈いては SSE 終了直後の值を測定しているので運動中の值とし ての信頼性が低いと考えられる. 本研究において も扗張期血圧は, SSE 終了とともに急減し，10秒 前後で安静値に達した.

血圧は SSE 開始とともに増加するが，収縮期 血圧も払張期血圧もともに 5 10秒の間で一時的 に低下した。 このような SSE 初期の血圧低下は Duncan et al.8) のイスを使った実験でも認められ ている.そのメカニズムとしては, SSE 開始時の 作業筋の血管払張に比べて, 腹部内臓の血管収縮 が遅れることによって起こる一時的なアンバラン スが考えられる.末梢血管抵抗が SSE 開始とと もに急减し，以後若干増加する傾向を示したの は, この推察を裏付けているのであろら. 一方, Vatner et al. ${ }^{25)}$ はSSE 初期に冠血流量が一時的 に减少することがあるが，これは動脈血圧の初期 減少と関係すると報告している. この考え方に従 えば, SSE 初期の動脈血圧低下が心筋虚血の指標 になりうる可能性がある.

収縮期血圧は SSE 終了とともに一旦急減し, リバウンドしてから, 周期 $2 \sim 3$ 分の上下变動を しながら回復する傾向を示したが，W-up を行っ た場合にはこのリバゥンドは消失ないし軽減し た. 6 人の被験者の回復時の一回拍出量と収縮期 血圧の beat-by-beat モードの変化を比較してみ ると, SSE 終了直後収縮期血圧が一時的に急减し た部分を除けば両者のパターンがかなり似てい る. したがって回復時の収縮期血圧の周期的变動 は一回拍出量の影響を受けているものと考えられ る. しかし SSE 終了直後の収縮期血圧の一時的 な急减現象は末梢血管抵抗の急减によるものと見 られる. 末梢血管抵抗が急减した原因としては, 作業筋の収縮による血管への圧迫が SSE 終了と ともに解除されたことが考えられる．扗張期血圧 に比して収縮期血圧の回復は遅く, 特にコントロ 一ルに招いては回復10分目にもSSE 直前値を上 回る傾向を示した. 収縮期血圧と扗張期血圧はそ 
れぞれ心拍出量と末梢血管抵抗により強く影響さ れると言われている.この点から考えると SSE 終了後の収縮期血圧の回復が遅くなったのは心拍 出量の回復が遅かったことによるものであろらと 考えられる. 実際にコントロールにおいて心拍出 量は, 回復10分目にも $8.9 \pm 1.6 \mathrm{~L} / \mathrm{min}$ を示してお り, SSE 前值の $7.2 \pm 1.8 \mathrm{~L} / \mathrm{min}$ を上回っている. これに対して末梢血管抵抗は SSE 終了直後さら に急减した後回復に転じたものの, 回復10分目ま でSSE 直前値を下回った.

SSE 初期に見られた収縮期血圧の一時的低下 は，W-upによって消失し，インターバルが長く なると再び出現した。 このパターンは心拍数の場 合とよく似ているが，血圧低下は心拍数のノッチ より時間的に速く起こるので, 両者の発生原因は 異なるものと考えられる. SSE 時の動脈血圧の初 期低下は前述のように心筋虚血性反応を招く可能 性がある251.これが事実であるならば今回の結果 は，W-upによって血圧の一時的低下を予防し， 心筋虚血性反応を予防することが可能であること を示している．W-upによって収縮期血圧の初期 低下が防止できた原因としては，W-upによって 末梢血管抵抗が既に SSE に適した状態まで低下 していたため, SSE 開始による末梢血管抵抗の急 减現象が防げたことが挙げられる.以上のような 収縮期血圧に見られた W-up 効果は扗張期血圧 の初期低下に対しても軽度ながら認められた.

収縮期血圧の SSE 中のピーク值は，W-up を 行っても有意な変化を示さなかった. 変化量につ いても同様であった．しかし時定数はW-up(5) においてコントロールより有意に短縮 し, W-up (30)に怙いては逆に有意に延長する傾向が得られ た、したがって，W-up はインターバルが短い場 合には, SSE 時の収縮期血圧の立ち上がりを加速 する効果があるが，インターバルが長くなるとそ の効果は消失し，さらに長くなると逆の効果を発 揮するものと見られる.

払張期血圧の SSE 中のピーク值は W-up (5) と W-up $(10)$ において有意に高く, 变化量も同様で あった. 心筋酸素供給の不足が問題になる SSE 時には，拡張期血圧がある程度高い方が望ましい
と考えられる.この点からいえば W-up はイン ターバルが短い方が望ましいといえるかもしれな い.しかしこの点に関しては，実際に心筋虚血像 を示寸被験者を対象にしてさらに検討する必要が ある。

回復時の時定数は収縮期血圧に打いて，W-up によって著しい短縮を示した、また変化量も収縮 期血圧，払張期血圧ともに，W-up した方がュン トロールより大きかった．これは W-up によっ て血圧の回復が加速されたことを意味するのであ る. その原因の一つとして，心拍出量の速い回復 が挙げられる. 実際に回復時の心拍出量の時定数

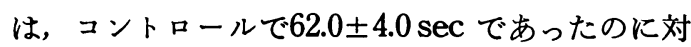
して, W-up(5)では $49.6 \pm 10.9 \mathrm{sec}, \mathrm{W} \cdot \mathrm{up}(10)$ で

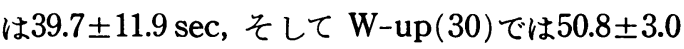
sec であり，W-up した方が有意に短かった. $\mathrm{W}-\mathrm{up}(30)$ の回復時の血圧の変化量はコントロー ルのそれとほぼ同じであったが，時定数はW-up (10)に比して有意に長かった。すなわち W-up の血圧の回復を加速する効果はインターバルが 30分以上になるとほぼ消失するものとみられる.

一方，結果の節で示したよらに，末梢血管抵抗 はW-upによって低下寸るが，この効果はW-up 後30分経過してもあまり消失しないことが明らか にされた。

\section{V. と め}

A. SSE 時の心拍数のノッチ現象はW-up に よって防止することができた．その原因として は，W-upによって運動開始時に副交感神経緊張 が最初からある程度低下していたことが考えられ た。

B. 心拍数と一回拍出量の立ち上がりの時定数 はインターバルが長いW-up によって短縮され たのに対して，血圧の場合にはインターバルが短 いW-upによって短縮した.

C. 一回拍出量は SSE 終了直後に急増した. その原因としては後負荷の減少と前負荷の增大が 考えられた。

D. SSE 時には収縮期血圧だけでなく㧪張 期 血圧も上昇した. 
E. SSE 初期に, 血圧の一時的低下が見られた が，W-upによって，収縮期血圧においては完全 に，抁張期血圧においてはある程度弱められた。 このよらな W-up 効果は心筋虚血性反応の予防 効果と関わるものと考えられた.

F. W-upによって，全てのパラメーターにお いて回復時の時定数は短縮し, 回復が加速される ことを示した. また心拍数を除いては変化量も増 大したが，そのような効果は30分のインターバル でほぼ消失した。

以上の所見から，以下のことが結論できる.

A. 激しい運動を急に始めると, 各循環パラメ ーターは急激に変化するが，その変動パターンは パラメーターによって異なり，それぞれ特徵的な 像を示す.

B. 事前に W-up を行らと, 循環反応の立ち上 がりは概して加速される傾向を示すが, インター バルの長さの影響を強く受け，必ずしも常に同一 の傾向をとるとは限らない，W-up は特に循環系 の回復を加速させるが，このような W-up 効果 は, 今回の実験条件に拈いては約30分でほぼ消失 する.

(受付 平成 2 年 4 月 2 日)

\section{Reference}

1) Andzel, W. D. (1978): The effects of moderate prior exercise and varied rest intervals upon cardiorespiratory endurance. J. Sports Med., 18, 245-252.

2) Andzel, W. D. and Busuttil, C. (1982) : Metabolic and physiological response of college female to prior exercise, varied rest intervals and strenuous endurance task. J. Sports Med., 22, 113-119.

3) Astrand, P. O. and Rodahl, K.(1986) : Textbook of work physiology, 3 rd Ed., New York, McgrawHill.

4) Barnard, R. J., Gardner, G. W., Diaco, N. V., MAcAlpin, R. N. and Kattus, A. A. (1973): Cardiovascular response to sudden strenuous exercise-HR, BP, and ECG. J. Appl. physiol., 34(6), 833-837.

5) Barnard, R. J., MAcAlpin, R. N., Kattus, A. A. and Buckberg, G. D. (1973) : Ischemic response to sudden strenuous exercise in healthy men. Circulation, 48, 936-942.

6) Buckberg, G. D., Fixler, D. E., Archie, J. P. and Hoffman, J. I. E. (1972) : Exprimental subendocardial ischemia in dogs with normal coronary arteries. Circulation Res., 30, 67-81.

7) Duncan, H. W., Grimditch, G. K. and Barnard, R. J. (1979) : Cardio response to sudden strenuous exercise (abstract). Med. Sci. Sports, 11-86.

8) Duncan, H. W., Grimditch, G. K., Barnard, R. J., Vinten, Johansen, J. and Buckberg, G. D.(1987) : Cardiovascular response to sudden strenuous exercise. Basis, Res. Cardiol., 82, 226-232.

9) Forster, C., Anholm, J. D., Hellman, C. K., Carpenter, J., Pollock, M. L. and Sehmidt, D. H. (1981) : Left ventricular function during sudden strenuous exercise. Circulation, 63, 592-596.

10) Forster, C., Dymond, D., Carpenter, J. and Donard, H. (1982) : Effect of warming-up on left ventricular response to sudden strenuous exercise. J. Appl. Physiol., 53(2), 380-383.

11) 後藤真二(1988)：ウォーミング・アップが運動パフ オーマンスおよびェネルギー代謝に及ぼす影響. 筑 波大学体有科学研究科博上論文, 24-69.

12) Gutin, B., Kruper, J., Lewis, S. and Stewart, K. (1976) : Oxygen consumption in the first stages of strenuous work as a function of prior exercise. J. Sports Med., 16, 60-65.

13) Hagberg, J. M., Hickson, R. C., Ehsani, A. A. and Holloszy, J. O. (1980) : Faster adjustment to and recovery from submaximal exercise in the trained state. J. Appl. Physiol., 48(2), 218-224.

14）池上晴夫, 西保 匠, 鍋倉賢治, 福岡義之, 権 五 戟(1989)：心周期分画および一回拍出量の beatby-beat 自動測定法の開発. 筑波大学体有科学系紀 要, 12, 153-159.

15) Inger, F. and Stromme, S. B. (1979) : Effect of active, passive or no warming-up on the physical response to heavy exercise. Eur. J. Appl. Physiol., 40, 273-282.

16) Jaffe, M. D. and Quinn, N. K. (1980) : Warmingup phenomenon in angina pectoris. Lancet, 2, 8201, 934-936. 
17) 古賀俊策 (1989)：定常運動と非定常運動におけるカ ス交換動態の beat-by-beat 法による研究. 筑波大 学体育科学研究科博士論文, 51-76.

18) Linnarsson, D. (1974) : Dynamics of pulmonary gas exchange and heart rate changes at start and end of exercise. Acta. Physiol. Scand. Suppl., 415, 1-68.

19) Mckenna, M. J., Green, R. A., Shaw, P. F. and Mayer, A. D. (1987) : Test of anaerobic power and capacity. Aust. J. Sci. Med. Sports, 19(2), 13-17.

20）鍋倉賢治，西保 岳, 山田由紀子, 池上晴夫(1989)： 耳架脈微分波による左室駆出時間の測定法に関する 研究. 体力科学, 38(1), 27-37.

21) Radice, M., Alli, C., Avanzini, F., Ditullio, M. and Mariotti, G. (1985) : Role of blood pressure response to provocative tests in the prediction of hypertension in adolescents. Eur. Heart J., 6, 490496.

22) Richard, L. and Michelle, M. (1982) : Delayed kinetics of respiratory gas exchange in the tran- sition from prior exercise. J. Appl. Physiol., 52, 921-929.

23) Richard, R. N., Predrick, L. G., Charles, K. J., Kyuhyun, W., Yang, W. and Henry, L. T.(1974) : Hemodynamic predictors of myocardior oxygen consumption during static and dynamic exercise. Circulation, 50, 1179-1189.

24) Stein, R. A., Berger, H. G. and Zaret, B. L.(1986) : The cardiac response to sudden strenuous exercise in the post-myocardial infarction patient receiving beta blockers. J. Cardiopulm. Rehabil., 6(9), 336-342.

25) Vatner, S. F., Higgins, C. B., Franklin, D. and Braunward, E. (1972) : Role of tachycardia in mediating the coronary hemodynamic response to severe exercise. J. Appl. Physiol., 32(3), 380-385.

26) Versteeg, P. G. A., Sampurno, S. D., Sipkema, P. and Elzinga, G.(1981) : Control of cardiac output in the exercising dogs different types of work load. Cardiovasc. Res., 15, 151-158. 